\title{
Temporal variations of dimethylsulfide and dimethylsulfoniopropionate in the southern Yellow Sea in spring and autumn
}

\author{
YANG Jian $^{1,2}{ }^{2}$ YANG Guipeng ${ }^{1 *}$, ZHANG Honghai ${ }^{1}$, ZHANG Shenghui $^{1}$ \\ ${ }^{1}$ Key Laboratory of Ministry of Education for Marine Chemistry Theory and Technology, College of Chemistry and \\ Chemical Engineering, Ocean University of China, Qingdao 266100, China \\ ${ }^{2}$ Coastal Environment Engineering Technology Research Center of Shandong Province, Yantai Institute of Coastal \\ Zone Research, Chinese Academy of Sciences, Yantai 264003, China
}

Received 30 July 2014; accepted 26 February 2015

(c) The Chinese Society of Oceanography and Springer-Verlag Berlin Heidelberg 2016

\begin{abstract}
Temporal distributions of dimethylsulfide (DMS) and dimethylsulfoniopropionate (DMSP) were studied in the southern Yellow Sea (SYS) during April and September 2010. The mean concentrations (range) of DMS, dissolved and particulate DMSP (DMSPd and DMSPp) in the surface waters in spring are 1.69 (0.48-4.92), $3.18(0.68-6.75)$ and $15.81(2.82-52.33) \mathrm{nmol} / \mathrm{L}$, respectively, and those in autumn are 2.80 (1.33-5.10), 5.45 (2.19-11.30) and 30.63 (6.24-137.87) $\mathrm{nmol} / \mathrm{L}$. On the whole, the distributions of DMS and DMSP in spring are completely different from those in autumn. In the central part of the SYS, the concentrations of DMS and DMSP in spring are obviously higher than those in autumn, but the opposite situation is found on the south of $34^{\circ} \mathrm{N}$, which can be attributed to the differences in nutrients and phytoplankton biomass and composition between spring and autumn. Besides, the seasonal variations of water column stability and the Changjiang diluted water also have significant impact on the distributions of DMS and DMSP in spring and autumn on the south of $34^{\circ} \mathrm{N}$. DMS and DMSPp concentrations coincide well with chlorophyll $a(\mathrm{Chl} a)$ levels in the spring cruise, suggesting that phytoplankton biomass may play an important role in controlling the distributions of DMS and DMSPp in the study area. Annual DMS emission rates range from 0.015 to $0.033 \mathrm{Tg} / \mathrm{a}$ (calculated by S), respectively, using the equations of Liss and Merlivat (1986) and Wanninkhof (1992). This result implies a significant relative contribution of the SYS to the global oceanic DMS fluxes.
\end{abstract}

Key words: dimethylsulfide, dimethylsulfoniopropionate, chlorophyll $a$, sea-to-air flux, the southern Yellow Sea

Citation: Yang Jian, Yang Guipeng, Zhang Honghai, Zhang Shenghui. 2016. Temporal variations of dimethylsulfide and dimethylsulfoniopropionate in the southern Yellow Sea in spring and autumn. Acta Oceanologica Sinica, 35(2): 76-87, doi: 10.1007/s13131-015-0780-y

\section{Introduction}

Dimethylsuldife (DMS) is an important sulfur trace gas of climatic significance. In recent years, more and more attentions have been paid to DMS and its related compounds since Lovelock et al. (1972) pointed out that DMS was enriched in the sea surface and led to a significant sea-to-air flux. DMS in sea water, which takes a large proportion in biogenic sulfur emissions from the ocean, plays an important climatic role by forming methanesulfonate (MSA) and sulfate aerosols in the atmosphere, finally leading to the formation of cloud condensation nuclei and thereby influencing cloud albedo (Charlson et al., 1987). In addition, DMS could also contribute to the acidity of rainfall (Bates et al., 1987; Nguyen et al., 1992).

DMS is produced in the ocean from the cleavage of dimethylsulfoniopropionate (DMSP) by DMSP-lyases contained in some marine bacteria and a few species of phytoplankton, where it acts as a compatible solute to counter various stresses, including osmotic, oxidative, and potential damage by UV light (Sunda et al., 2002). Dinoflagellates and prymnesiophytes are known to be im- portant DMSP producers, while diatoms generally contain low DMSP concentration (Keller et al., 1989). However, Shenoy et al. (2006) reported that DMS was linearly related to the ratio of chlorophyll $a /$ phaeopigments in some diatom-dominated waters, suggesting that diatoms also might play an important role in the biogeochemical cycling of DMS. Besides, the cleavage and release of DMSP could be accelerated by algal senescence, grazing or viral attack (Dacey and Wakeham, 1986; Levasseur et al., 1996; $\mathrm{Li}$ et al., 2010). Once DMS is produced in sea water, it is rapidly removed by various processes such as bacterial metabolism, photochemical oxidation and emission to the atmosphere. Galí et al. (2011) reported that bacterial consumption was the dominant sink for DMS which accounted for $9 \%-73 \%$ of its loss in the upper mixed layer in the arctic, while photolysis became the dominant sink at some stations which occupied $12 \%-65 \%$ of the total DMS loss. In contrast, the sea-to-air emission may represent only a small fraction of sink for DMS in sea water, even though the total amount of DMS emanating from the ocean to the atmosphere is significant on a global scale (Bates et al., 1994).

Foundation item: The National Natural Science Foundation of China under contract Nos 41320104008, 41306069 and 41106071 ; the Changjiang Scholars Programme, the Ministry of Education of China; the Taishan Scholar Programme of Shandong Province; the Fundamental Research Funds for the Central Universities.

${ }^{*}$ Corresponding author, E-mail: gpyang@ouc.edu.cn 
The concentrations of DMS in the sea surface show a considerable spatial and temporal variation (Kettle and Andreae, 2000; Uher et al., 2000). In general, higher values of DMSP and DMS are found in eutrophic coastal areas and in the regions of upwelling than in oligotrophic open ocean waters. Shenoy and Dileep Kumar (2007) reported that the highest concentrations of DMS and DMSP were found in upwelling regimes along the west coast of India in the monsoon seasons. Besides, due to differences in environmental, biological and chemical factors, the concentrations of DMS and DMSP varied significantly with season. Shenoy and Patil (2003) reported the significant variability in DMSP and DMS concentrations after 14 months of observation, with the maximal concentrations occurring in the dinoflagellate bloom season. Although the great efforts have been made to investigate the distributions of DMS and DMSP in the marginal seas of China (Yang et al., 2000, 2006, 2008, 2012), very limited data are available for the comparison of variations in DMS and DMSP among different seasons in the marginal seas of China. For instance, Yang et al. (2011) investigated the seasonal variations of DMS and DMSP in the East China Sea and the SYS during summer and winter. In the present study, we investigated the spatiotemporal distributions of DMS and DMSP in the SYS during spring and autumn and probed into biogeochemical factors influencing their seasonal availability, such as nutrients and phytoplankton biomass. The sea-to-air fluxes of DMS in the study area were also calculated for assessing the contribution of the SYS to global oceanic DMS emissions.

\section{Methods}

\subsection{Study area}

The Yellow Sea is a shallow, semi-enclosed marginal sea of the northwest Pacific Ocean with an average depth of about $44 \mathrm{~m}$. It is located between China and Korea and is bounded to the north by the Bohai Sea and to the south by the East China Sea. The boundary between the northern Yellow Sea and the SYS is often taken to be from the Chengshan Cape to the Changsan-got. The SYS is dominated by a strong northerly monsoon from late November to early April. By the end of May, the southerly wind begins and continues throughout the summer (Mask et al., 1998). Spring and autumn are the transitional seasons when the wind direction is variable.

The hydrographic characteristics of the SYS are greatly influenced by some circulations, including the Yellow Sea Warm Current on the eastern side and the Subei coastal current on the western side. The Yellow Sea Warm Current is a branch of the Tsushima Warm Current and flows from the southeast to the northwest, with a characteristic of high temperature and high salinity (Su, 1998). It is widely accepted that the Yellow Sea Warm Current is stronger in winter and is very week or vanishes in summer, with a significant impact on the transport of mass and a heat flux between the East China Sea and the Yellow Sea (Zhang et al., 2008). A tidal front divides the SYS into the well-mixed shallow regions and the highly stratified deeper regions occupied by the Yellow Sea Cold Water Mass (Liu et al., 2008). The Yellow Sea Cold Water Mass forms in late spring and disappears in late autumn for about half a year, which plays an important role in controlling the phytoplankton biomass and the primary production in the Yellow Sea by recycling of chemical substances under the confluence of warm and cold waters. In the mixed shallow regions, abundant land-source materials can be emptied into the Yellow Sea along the river, especially in the Changjiang River Estuary and its adjacent areas. In spring, under the high runoff and the prevailing southerly monsoon, a part of Changjiang diluted water with a large amount of nutrients extends to the northeast into the Subei coastal area that provides conditions favorable for the biologic production in the coastal waters.

\subsection{Sampling}

Two cruises were conducted aboard the R/V Dongfanghong No. 2 in the SYS from 21 to 29 in April and from 8 to 15 in September of 2010, respectively. The sampling stations are shown in Fig. 1. The surface water samples were collected using 12 L Niskin bottles mounted on a Seabird 911 CTD. Detailed information about the sampling stations and hydrographic parameters are described in Table 1 (spring) and Table 2 (autumn). The surface water temperature, the salinity and the water depth were obtained from the CTD apparatus.

\subsection{Analytical procedures}

All DMS samples were immediately analyzed on board after
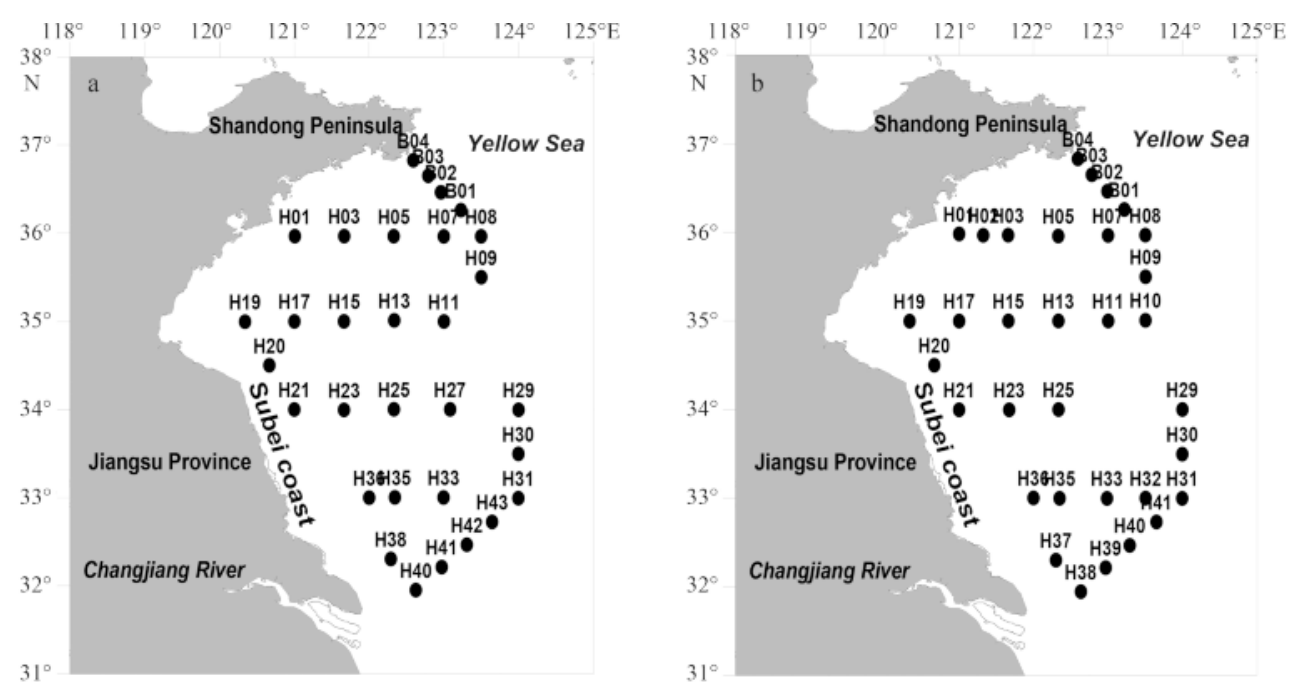

Fig. 1. Location of the sampling station in the SYS during spring (a) and autumn (b). 
Table 1. Summary of sampling stations and their chlorophyll $a$, DMS and DMSP concentrations in the SYS in spring

\begin{tabular}{|c|c|c|c|c|c|c|c|c|c|c|c|c|}
\hline Station & $\begin{array}{l}\text { North } \\
\text { latitude }\end{array}$ & $\begin{array}{c}\text { East } \\
\text { longtitude }\end{array}$ & $\begin{array}{l}\text { Temperature/ } \\
{ }^{\circ} \mathrm{C}\end{array}$ & Salinity & $\begin{array}{l}\text { Wind } \\
\text { speed/ } \\
\mathrm{m} \cdot \mathrm{s}^{-1}\end{array}$ & $\begin{array}{c}\text { Water } \\
\text { depth/ } \\
\text { m }\end{array}$ & $\begin{array}{c}\text { Depth } \\
\text { sampled/ } \\
\text { m }\end{array}$ & $\begin{array}{c}\text { Mixed } \\
\text { layer } \\
\text { depth } / \mathrm{m}\end{array}$ & $\begin{array}{c}\text { DMS/ } \\
\mathrm{nmol} \cdot \mathrm{L}^{-1}\end{array}$ & $\begin{array}{l}\text { DMSPd/ } \\
\text { nmol } \cdot \mathrm{L}^{-1}\end{array}$ & $\begin{array}{l}\text { DMSPp/ } \\
\mathrm{nmol} \cdot \mathrm{L}^{-1}\end{array}$ & $\begin{array}{l}\text { Chl } a / \\
\mu \mathrm{g} \cdot \mathrm{L}^{-1}\end{array}$ \\
\hline H01 & $35^{\circ} 58.049^{\prime}$ & $121^{\circ} 0.418^{\prime}$ & 7.03 & 31.985 & - & 35.0 & 3.0 & 8.0 & 0.80 & 3.79 & 38.51 & 0.26 \\
\hline H03 & $35^{\circ} 58.059^{\prime}$ & $121^{\circ} 40.029^{\prime}$ & 6.57 & 31.945 & 4.7 & 37.0 & 2.1 & 2.0 & 0.74 & 2.96 & 41.38 & 0.18 \\
\hline H05 & $35^{\circ} 58.035^{\prime}$ & $122^{\circ} 19.766^{\prime}$ & 6.61 & 31.974 & 9.8 & 56.4 & 3.1 & - & 0.69 & 4.43 & 29.23 & 0.47 \\
\hline H07 & $35^{\circ} 57.890^{\prime}$ & $122^{\circ} 59.945^{\prime}$ & 8.12 & 32.467 & 9.4 & 71.4 & 2.1 & 15.0 & 2.41 & 4.02 & 22.42 & 0.99 \\
\hline H08 & $35^{\circ} 57.928^{\prime}$ & $123^{\circ} 29.908^{\prime}$ & 8.98 & 32.677 & 9.0 & 76.0 & 2.4 & 21.0 & 3.34 & 6.43 & 52.33 & 11.52 \\
\hline H09 & $35^{\circ} 30.075^{\prime}$ & $123^{\circ} 30.037^{\prime}$ & 9.02 & 32.751 & 11.4 & 76.0 & 2.2 & 21.0 & 4.19 & 6.66 & 39.76 & 3.90 \\
\hline H11 & $34^{\circ} 59.958^{\prime}$ & $123^{\circ} 0.075^{\prime}$ & 9.80 & 33.209 & 9.9 & 73.0 & 2.9 & 18.0 & 4.92 & 6.75 & 34.79 & 6.87 \\
\hline H13 & $35^{\circ} 0.695^{\prime}$ & $122^{\circ} 20.192^{\prime}$ & 7.84 & 32.258 & 11.9 & 62.0 & 4.2 & 21.0 & 3.38 & 3.65 & 25.78 & 0.84 \\
\hline H15 & $35^{\circ} 0.033^{\prime}$ & $121^{\circ} 39.847^{\prime}$ & 7.78 & 32.172 & 8.1 & 47.2 & 2.8 & 30.0 & 2.16 & 3.56 & 19.39 & 0.31 \\
\hline H17 & $34^{\circ} 59.997^{\prime}$ & $121^{\circ} 0.056^{\prime}$ & 8.05 & 32.059 & 5.8 & 39.0 & 2.2 & 37.0 & 1.54 & 4.53 & 9.68 & 0.46 \\
\hline H19 & $34^{\circ} 59.792^{\prime}$ & $120^{\circ} 20.431^{\prime}$ & 8.11 & 31.853 & 4.5 & 29.0 & 2.7 & 27.0 & 2.77 & 4.95 & 10.84 & 0.61 \\
\hline $\mathrm{H} 20$ & $34^{\circ} 30.111^{\prime}$ & $120^{\circ} 39.941^{\prime}$ & 8.89 & 30.237 & 3.5 & 21.0 & 1.6 & 11.0 & 0.93 & 1.63 & 5.75 & 0.45 \\
\hline $\mathrm{H} 21$ & $34^{\circ} 0.008^{\prime}$ & $120^{\circ} 59.986^{\prime}$ & 9.36 & 30.082 & 4.3 & 19.2 & 3.1 & 13.0 & 0.97 & 1.15 & 4.69 & 0.20 \\
\hline H23 & $33^{\circ} 59.736^{\prime}$ & $121^{\circ} 39.865^{\prime}$ & 9.83 & 32.421 & 7.7 & 20.0 & 2.7 & 17.0 & 0.93 & 1.41 & 4.76 & 0.76 \\
\hline H25 & $34^{\circ} 0.148^{\prime}$ & $122^{\circ} 19.927^{\prime}$ & 9.43 & 32.755 & 6.9 & 40.7 & 2.9 & 22.0 & 2.61 & 3.51 & 15.02 & 1.79 \\
\hline $\mathrm{H} 27$ & $34^{\circ} 0.098^{\prime}$ & $123^{\circ} 5.018^{\prime}$ & 10.74 & 33.769 & 8.5 & 70.0 & 2.6 & 26.0 & 1.02 & 3.5 & 13.03 & 1.10 \\
\hline H29 & $33^{\circ} 59.802^{\prime}$ & $123^{\circ} 59.955^{\prime}$ & 9.98 & 33.122 & 5.6 & 80.0 & 2.7 & 14.0 & 3.53 & 4.91 & 23.08 & 3.03 \\
\hline H30 & $33^{\circ} 29.791^{\prime}$ & $123^{\circ} 59.795^{\prime}$ & 11.03 & 33.362 & 4.2 & 70.4 & 2.4 & 15.0 & 1.78 & 3.66 & 14.70 & 1.33 \\
\hline H31 & $32^{\circ} 59.629^{\prime}$ & $123^{\circ} 59.763^{\prime}$ & 10.09 & 32.27 & 4.2 & 49.2 & 2.6 & 11.0 & 1.23 & 2.68 & 11.38 & 0.72 \\
\hline H33 & $33^{\circ} 0.113^{\prime}$ & $122^{\circ} 59.740^{\prime}$ & 9.88 & 32.423 & 0.9 & 34.0 & 2.5 & 18.0 & 1.10 & 3.29 & 7.08 & 0.58 \\
\hline H35 & $33^{\circ} 0.183^{\prime}$ & $122^{\circ} 20.671^{\prime}$ & 9.91 & 32.603 & 2.6 & 27.3 & 2.4 & 26.0 & 1.18 & 2.49 & 5.77 & 0.51 \\
\hline H36 & $32^{\circ} 59.982^{\prime}$ & $122^{\circ} 0.059^{\prime}$ & 10.81 & 32.427 & 1.3 & 15.0 & 2.9 & 13.0 & 1.23 & 2.30 & 6.24 & 0.89 \\
\hline H38 & $32^{\circ} 18.223^{\prime}$ & $122^{\circ} 17.434^{\prime}$ & 10.51 & 30.956 & 4.0 & 25.0 & 2.4 & 4.0 & 1.10 & 2.05 & 8.44 & 0.31 \\
\hline $\mathrm{H} 40$ & $31^{\circ} 57.038^{\prime}$ & $122^{\circ} 37.500^{\prime}$ & 11.20 & 31.576 & 3.0 & 32.0 & 2.1 & 5.0 & 0.48 & 0.68 & 3.46 & 0.25 \\
\hline H41 & $32^{\circ} 12.717^{\prime}$ & $122^{\circ} 58.300^{\prime}$ & 10.78 & 31.905 & 5.2 & 35.7 & 2.5 & 10.0 & 1.03 & 1.50 & 3.50 & 0.29 \\
\hline H42 & $32^{\circ} 27.925^{\prime}$ & $123^{\circ} 18.416^{\prime}$ & 10.61 & 32.081 & 4.4 & 38.6 & 2.6 & 14.0 & 1.02 & 1.48 & 2.82 & 0.46 \\
\hline H43 & $32^{\circ} 43.470^{\prime}$ & $123^{\circ} 38.701^{\prime}$ & 10.35 & 31.810 & 3.5 & 41.0 & 2.3 & 9.0 & 1.36 & 2.75 & 5.18 & 0.67 \\
\hline B01 & $36^{\circ} 15.753^{\prime}$ & $123^{\circ} 13.687^{\prime}$ & 8.48 & 32.628 & 15.2 & 78.0 & 2.9 & 61.0 & 1.47 & 2.21 & 6.36 & 1.40 \\
\hline B02 & $36^{\circ} 27.927^{\prime}$ & $122^{\circ} 57.642^{\prime}$ & 6.63 & 32.221 & 14.7 & - & 5.4 & 55.0 & 0.78 & 2.06 & 5.62 & 0.31 \\
\hline B03 & $36^{\circ} 39.172^{\prime}$ & $122^{\circ} 47.464^{\prime}$ & 6.83 & 32.343 & 9.8 & 24.4 & 2.2 & 20.0 & 0.82 & 2.46 & 12.93 & 1.63 \\
\hline B04 & $36^{\circ} 49.684^{\prime}$ & $122^{\circ} 35.485^{\prime}$ & 5.74 & 31.863 & 8.2 & 38.0 & 3.3 & 34.0 & 0.81 & 1.28 & 6.07 & 0.54 \\
\hline Average & - & - & 9.00 & 32.200 & 6.7 & 45.4 & 2.7 & 19.9 & 1.69 & 3.18 & 15.81 & 1.41 \\
\hline
\end{tabular}

collection, using the cryogenic purge-and-trap technique (Zhang et al., 2008). An aliquot of sea water $(10 \mathrm{~mL})$ was injected directly into a glass bubbling chamber through a glass syringe. The DMS in sea water was stripped with high purity nitrogen, dried through a glass tube containing $\mathrm{CaCl}_{2}$ and then trapped in an inert stainless steel U-shaped tube packed with Tenax-TA at the temperature of dry ice-ethanol $\left(-78^{\circ} \mathrm{C}\right)$. Then the gases extracted in the U-shaped tube were heated and introduced into a Shimadzu GC-14B gas chromatograph equipped with a flame photometric detector for analysis. A 3-m glass chromatographic column packed with $10 \%$ DEGS on Chromosorb W-AW-DMGS was used to separate sulfur gases. A calibration was based on addition of gravimetrically prepared standards of DMS in ethylene glycol solution to degassed sea water which was then subjected to the same procedure as sea water samples. The analytical precision was generally better than $5 \%$ in a routine sample analysis and the detection limit was approximately 0.1 pmol DMS.

DMSP samples were analyzed after alkaline cleavage to DMS in 1:1 stoichiometry (Dacey and Blough, 1987). In the analytical procedure, a gravity-filtration method was applied for separating DMSPd and DMSPp (Yang et al., 2005, 2008). An aliquot of $38 \mathrm{~mL}$ of sea water sample was filtered under gravity through a What- man GF/F filter. The filtrate was added into a $40 \mathrm{~mL}$ brown glass vial containing $2 \mathrm{~mL}$ of $10 \mathrm{~mol} / \mathrm{L} \mathrm{KOH}$ solution and immediately crimp-sealed with a rubber septum and aluminum lid, leaving no headspace. For DMSPp sample, the filter was rapidly placed in another vial filled with $38 \mathrm{~mL}$ distilled water and $2 \mathrm{~mL}$ of 10 $\mathrm{mol} / \mathrm{L} \mathrm{KOH}$ solution and then sealed. These DMSP samples were alkali-hydrolyzed in the dark at $4^{\circ} \mathrm{C}$ for at least $24 \mathrm{~h}$. DMS generated from the breakdown of DMSP was analyzed as described above. The concentration of DMSPd was calculated by subtracting DMS concentration from the sum of DMS and DMSPd concentrations.

For chlorophyll $a$ analysis, $300 \mathrm{~mL}$ of sea water was filtered through $47 \mathrm{~mm}$ Whatman GF/F filter and the filters were soaked in $10 \mathrm{~mL} 90 \%$ acetone which were kept in the dark at $4^{\circ} \mathrm{C}$. After 24 $\mathrm{h}$, the concentrations of chlorophyll $a$ were measured using a HITACHI F-4500 fluorometer according to Parsons et al. (1984). The filtrate was poured into a $100 \mathrm{~mL}$ plastic bottle and kept in $-20^{\circ} \mathrm{C}$ for nutrients determination. The concentrations of nitrate $\left(\mathrm{NO}_{3}^{-}\right)$, nitrite $\left(\mathrm{NO}_{2}^{-}\right)$, ammonium salt $\left(\mathrm{NH}_{4}^{+}\right)$, phosphate $\left(\mathrm{PO}_{4}^{3-}\right)$ and silicate $\left(\mathrm{SiO}_{3}^{2-}\right)$ were quantified using an autoanalyzer (Seal Analytical AA3). The dissolved inorganic nitrogen (DIN) concentration is the sum of $\mathrm{NO}_{3}^{-}, \mathrm{NO}_{2}^{-}$and $\mathrm{NH}_{4}^{+}$concentrations. 
Table 2. Summary of sampling stations and their chlorophyll $a$, DMS and DMSP concentrations in the SYS in autumn

\begin{tabular}{|c|c|c|c|c|c|c|c|c|c|c|c|c|}
\hline Station & $\begin{array}{l}\text { North } \\
\text { latitude }\end{array}$ & $\begin{array}{c}\text { East } \\
\text { longtitude }\end{array}$ & $\begin{array}{c}\text { Temperature/ } \\
{ }^{\circ} \mathrm{C}\end{array}$ & Salinity & $\begin{array}{c}\text { Wind } \\
\text { speed/ } \\
\mathrm{m} \cdot \mathrm{s}^{-1}\end{array}$ & $\begin{array}{c}\text { Water } \\
\text { depth/ } \\
\text { m }\end{array}$ & $\begin{array}{c}\text { Depth } \\
\text { sampled/ } \\
\text { m }\end{array}$ & $\begin{array}{c}\text { Mixed } \\
\text { layer } \\
\text { depth/m }\end{array}$ & $\begin{array}{c}\text { DMS/ } \\
\mathrm{nmol} \cdot \mathrm{L}^{-1}\end{array}$ & $\begin{array}{l}\text { DMSPd/ } \\
\mathrm{nmol} \cdot \mathrm{L}^{-1}\end{array}$ & 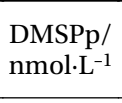 & $\begin{array}{l}\mathrm{Chl} a / \\
\mu \mathrm{g} \cdot \mathrm{L}^{-1}\end{array}$ \\
\hline H01 & $35^{\circ} 58.949^{\prime}$ & $120^{\circ} 59.979^{\prime}$ & 23.70 & 30.345 & 7.5 & 32.7 & 2.6 & 13.0 & 1.61 & 10.06 & 22.86 & 0.62 \\
\hline H02 & $35^{\circ} 58.023^{\prime}$ & $121^{\circ} 19.397^{\prime}$ & 23.75 & 30.092 & 9.2 & 37.3 & 2.3 & 8.0 & 2.01 & 5.03 & 24.70 & 0.55 \\
\hline H03 & $35^{\circ} 58.103^{\prime}$ & $121^{\circ} 39.486^{\prime}$ & 23.93 & 30.554 & 7.0 & 38.2 & 2.6 & 10.0 & 1.60 & 2.29 & 15.42 & 0.56 \\
\hline H05 & $35^{\circ} 57.536^{\prime}$ & $122^{\circ} 19.888^{\prime}$ & 23.97 & 29.999 & 2.9 & 54.0 & 2.4 & 1.0 & 1.50 & 5.78 & 23.12 & 0.63 \\
\hline H07 & $35^{\circ} 57.822^{\prime}$ & $123^{\circ} 0.021^{\prime}$ & 24.97 & 30.100 & 10.3 & 73.0 & 1.9 & 4.0 & 4.18 & 7.15 & 16.21 & 0.38 \\
\hline H08 & $35^{\circ} 58.138^{\prime}$ & $123^{\circ} 30.071^{\prime}$ & 26.64 & 31.224 & 10.6 & 76.0 & 1.4 & 4.0 & 2.61 & 9.44 & 21.12 & 0.61 \\
\hline H09 & $35^{\circ} 29.936^{\prime}$ & $123^{\circ} 30.242^{\prime}$ & 27.43 & 31.544 & 8.6 & 73.6 & 2.9 & 11.0 & 3.20 & 9.15 & 19.81 & 0.30 \\
\hline $\mathrm{H} 10$ & $35^{\circ} 0.430^{\prime}$ & $123^{\circ} 30.172^{\prime}$ & 27.50 & 31.383 & 8.2 & 77.6 & 2.0 & 18.0 & 2.30 & 8.83 & 16.22 & 0.41 \\
\hline H11 & $35^{\circ} 0.007^{\prime}$ & $123^{\circ} 0.146^{\prime}$ & 24.50 & 30.690 & 2.5 & 75.0 & 1.5 & 2.0 & 1.81 & 6.91 & 10.07 & 0.50 \\
\hline H13 & $35^{\circ} 0.023^{\prime}$ & $122^{\circ} 20.010^{\prime}$ & 24.72 & 30.291 & - & 61.5 & 2.4 & 8.0 & 2.08 & 6.16 & 11.62 & 0.59 \\
\hline H15 & $35^{\circ} 0.008^{\prime}$ & $121^{\circ} 39.685^{\prime}$ & 24.34 & 30.324 & 6.0 & 46.3 & 2.0 & 1.0 & 1.33 & 2.73 & 18.27 & 0.84 \\
\hline H17 & $34^{\circ} 59.940^{\prime}$ & $120^{\circ} 59.986^{\prime}$ & 24.76 & 30.305 & 6.4 & 37.0 & 2.1 & 2.0 & 1.33 & 3.26 & 18.95 & 1.11 \\
\hline H19 & $34^{\circ} 59.884^{\prime}$ & $120^{\circ} 20.067^{\prime}$ & 24.28 & 30.852 & 7.8 & 29.0 & 2.3 & 28.0 & 1.60 & 2.35 & 11.43 & 0.80 \\
\hline $\mathrm{H} 20$ & $34^{\circ} 30.035^{\prime}$ & $120^{\circ} 39.968^{\prime}$ & 24.32 & 30.894 & 6.8 & 19.6 & 2.1 & 18.0 & 1.61 & 2.28 & 13.30 & 0.82 \\
\hline $\mathrm{H} 21$ & $33^{\circ} 59.835^{\prime}$ & $120^{\circ} 59.951^{\prime}$ & 26.26 & 29.453 & 5.1 & 19.4 & 2.5 & 7.0 & 2.30 & 3.14 & 10.65 & 1.09 \\
\hline H23 & $33^{\circ} 59.810^{\prime}$ & $121^{\circ} 40.317^{\prime}$ & 26.29 & 29.908 & 7.3 & 20.0 & 1.9 & 9.0 & 1.58 & 3.40 & 12.32 & 0.53 \\
\hline $\mathrm{H} 25$ & $34^{\circ} 0.014^{\prime}$ & $122^{\circ} 20.093^{\prime}$ & 22.64 & 30.861 & 0.3 & 39.0 & 2.2 & 1.0 & 2.02 & 4.53 & 21.65 & 1.52 \\
\hline H29 & $34^{\circ} 0.033^{\prime}$ & $123^{\circ} 59.950^{\prime}$ & 27.99 & 30.466 & 2.5 & 80.9 & 2.2 & 1.0 & 2.62 & 2.82 & 21.66 & 1.49 \\
\hline H30 & $33^{\circ} 29.800^{\prime}$ & $123^{\circ} 59.838^{\prime}$ & 27.52 & 30.026 & 1.2 & 69.5 & 2.2 & 3.0 & 2.89 & 2.19 & 37.68 & 1.82 \\
\hline H31 & $32^{\circ} 59.852^{\prime}$ & $123^{\circ} 59.758^{\prime}$ & 26.24 & 29.785 & 3.9 & 48.3 & 2.2 & 4.0 & 6.02 & 8.87 & 67.84 & 4.16 \\
\hline H32 & $33^{\circ} 0.035^{\prime}$ & $123^{\circ} 30.259^{\prime}$ & 25.97 & 29.978 & 6.9 & 36.5 & 1.7 & 8.0 & 4.28 & 6.77 & 51.59 & 4.96 \\
\hline H33 & $32^{\circ} 59.848^{\prime}$ & $122^{\circ} 59.161^{\prime}$ & 25.97 & 31.026 & 6.7 & 32.9 & 2.2 & 2.0 & 3.28 & 3.74 & 18.34 & 0.51 \\
\hline H35 & $32^{\circ} 59.904^{\prime}$ & $122^{\circ} 20.955^{\prime}$ & 24.03 & 30.856 & 3.7 & 27.0 & 1.8 & 25.0 & 1.91 & 3.65 & 22.76 & 1.12 \\
\hline H36 & $33^{\circ} 0.159^{\prime}$ & $121^{\circ} 59.879^{\prime}$ & 25.21 & 30.744 & 2.6 & 18.8 & 2.5 & 16.0 & 1.43 & 2.79 & 6.24 & 0.94 \\
\hline H37 & $32^{\circ} 18.005^{\prime}$ & $122^{\circ} 18.007^{\prime}$ & 25.77 & 30.269 & 1.5 & 22.8 & 1.7 & 7.0 & 3.24 & 6.04 & 18.54 & 1.29 \\
\hline H38 & $31^{\circ} 56.672^{\prime}$ & $122^{\circ} 38.110^{\prime}$ & 24.91 & 30.888 & 2.4 & 29.7 & 2.2 & 2.0 & 3.24 & 3.93 & 27.15 & 1.53 \\
\hline H39 & $32^{\circ} 12.922^{\prime}$ & $122^{\circ} 58.098^{\prime}$ & 25.24 & 31.067 & 2.3 & 35.4 & 2.4 & 12.0 & 5.10 & 9.48 & 45.99 & 3.12 \\
\hline $\mathrm{H} 40$ & $32^{\circ} 28.010^{\prime}$ & $123^{\circ} 17.500^{\prime}$ & 25.30 & 30.774 & 3.7 & 39.5 & 2.0 & 2.0 & 7.95 & 11.30 & 58.57 & 1.33 \\
\hline $\mathrm{H} 41$ & $32^{\circ} 43.885^{\prime}$ & $123^{\circ} 39.021^{\prime}$ & 26.86 & 28.611 & 4.8 & 41.6 & 2.2 & 4.0 & 3.73 & 4.86 & 52.59 & 2.83 \\
\hline B01 & $36^{\circ} 15.474^{\prime}$ & $123^{\circ} 13.145^{\prime}$ & 24.75 & 30.189 & 2.1 & 75.6 & 2.7 & 2.0 & 2.38 & 2.67 & 25.67 & 0.30 \\
\hline B02 & $36^{\circ} 27.868^{\prime}$ & $122^{\circ} 59.463^{\prime}$ & 25.02 & 30.682 & 4.8 & 66.2 & 2.5 & 2.0 & 2.11 & 11.18 & 27.14 & 0.82 \\
\hline B03 & $36^{\circ} 39.014^{\prime}$ & $122^{\circ} 46.917^{\prime}$ & 24.28 & 30.661 & 3.3 & 24.8 & 2.2 & 2.0 & 4.63 & 3.24 & 103.34 & 0.89 \\
\hline B04 & $36^{\circ} 49.478^{\prime}$ & $122^{\circ} 35.671^{\prime}$ & 23.53 & 30.599 & 1.1 & 38.2 & 2.3 & 2.0 & 2.87 & 3.98 & 137.87 & 2.52 \\
\hline Average & - & - & 25.23 & 30.468 & 5.0 & 45.4 & 2.2 & 7.2 & 2.80 & 5.45 & 30.63 & 1.26 \\
\hline
\end{tabular}

Mixed layer depth was defined as the depth at which the water density increased by $0.03 \mathrm{~kg} / \mathrm{m}^{3}$ or the temperature dropped by $0.1^{\circ} \mathrm{C}$ (Lee et al., 2010).

The sea-to-air flux of DMS can be calculated according to the equation of Liss and Merlivat (1986),

$$
F=K \Delta c_{\mathrm{DMS}}=K c_{\mathrm{W}},
$$

where $K$ is gas transfer coefficient, $\Delta c_{\mathrm{DMS}}$ is the concentration difference of DMS in sea water and the atmosphere, which is actually equal to the concentration of dissolved DMS in the surface sea water $\left(c_{\mathrm{W}}\right)$, since atmospheric DMS concentration is generally 2-3 orders of magnitude lower than the concentration of dissolved DMS in the surface sea water. The two prevailing models of LM86 (Liss and Merlivat, 1986) and W92 (Wanninkhof, 1992) were used to calculate the gas transfer coefficients, respectively, which represent lower (LM86) and higher (W92) estimates in sea-air exchange parameterizations. The coefficient $K$ is calculated as a function of wind speed and the Schmidt number $(S c)$ (Liss and Merlivat, 1986). The Schmidt number of DMS at the local temperature is obtained using the equation put forward by
Saltzman et al. (1993). In this study, the wind speeds were measured at about $10 \mathrm{~m}$ above the sea surface by ship-borne weather instrument (RM Young, USA) and had been automatically corrected to true wind speeds.

\section{Results and discussion}

\subsection{The distribution characteristics of DMS and DMSP in spring and autumn}

The concentrations of DMS in the spring cruise ranged from 0.48 to $4.92 \mathrm{nmol} / \mathrm{L}$, with an average of $1.69 \mathrm{nmol} / \mathrm{L}$. The average concentrations of DMSPd and DMSPp were 3.18 (0.68-6.75) $\mathrm{nmol} / \mathrm{L}$ and $15.81(2.82-52.33) \mathrm{nmol} / \mathrm{L}$, respectively. Our results of DMS are in good agreement with those previously reported by Yang et al. (2006) who found that DMS concentrations in the Yellow Sea in spring varied from 1.20 to $4.54 \mathrm{nmol} / \mathrm{L}$, with an average of $2.31 \mathrm{nmol} / \mathrm{L}$. However, the average value of DMSPp concentration is roughly twice as much as that obtained in the same area in March 2005 (Yang et al., 2006), which might be attributed to the spring bloom in this cruise. In comparison, the concentrations of all sulfur species throughout the study area were higher 
in autumn than in spring. The concentrations of DMS, DMSPd and DMSPp in autumn fluctuated from 1.33 to $7.95,2.19$ to 11.30 and 6.24 to $137.87 \mathrm{nmol} / \mathrm{L}$, respectively, with average values of 2.80, 5.45 and $30.63 \mathrm{nmol} / \mathrm{L}$. Our results of DMS are consistent with previous measurements by $\mathrm{Hu}$ et al. (2003) who found that DMS concentrations in the Yellow Sea during September 1994 varied from 0.95 to $7.48 \mathrm{nmol} / \mathrm{L}$ with an average of $2.89 \mathrm{nmol} / \mathrm{L}$.

The concentrations of chlorophyll $a$ in spring and autumn varied from 0.18 to 11.52 and 0.30 to $4.96 \mu \mathrm{g} / \mathrm{L}$, respectively, with average values of 1.41 and $1.26 \mu \mathrm{g} / \mathrm{L}$. As shown in Fig. 2, high chlorophyll $a$ concentrations in spring occurred in the middle region of the SYS, with the highest value $(11.52 \mu \mathrm{g} / \mathrm{L})$ appearing at Sta. H08. This distribution pattern showed that a spring phytoplankton bloom took place in the region of the Yellow Sea Cold Water Mass during the investigation period. In contrast to the spring distribution, the low concentrations of chlorophyll $a$ appeared in the middle region of the SYS and the lowest concentration of chlorophyll $a$ was observed at Sta. H09 in autumn. On the south of $34^{\circ} \mathrm{N}$, the concentrations of chlorophyll $a$ were significantly higher in autumn than in spring (Fig. 2). Besides, the lower concentrations of chlorophyll $a$ were found in the Subei coastal waters in spring and autumn.

\subsection{Seasonal variations of DMS and DMSP in the SYS}

The seasonal variations could influence the phytoplankton parameters and the production processes of DMS and DMSP and eventually impacted on the concentrations of those sulfur compounds. Previous studies have shown that the seasonal variations of DMS and DMSP concentrations are associated with phytoplankton parameters such as species, biomass and growth

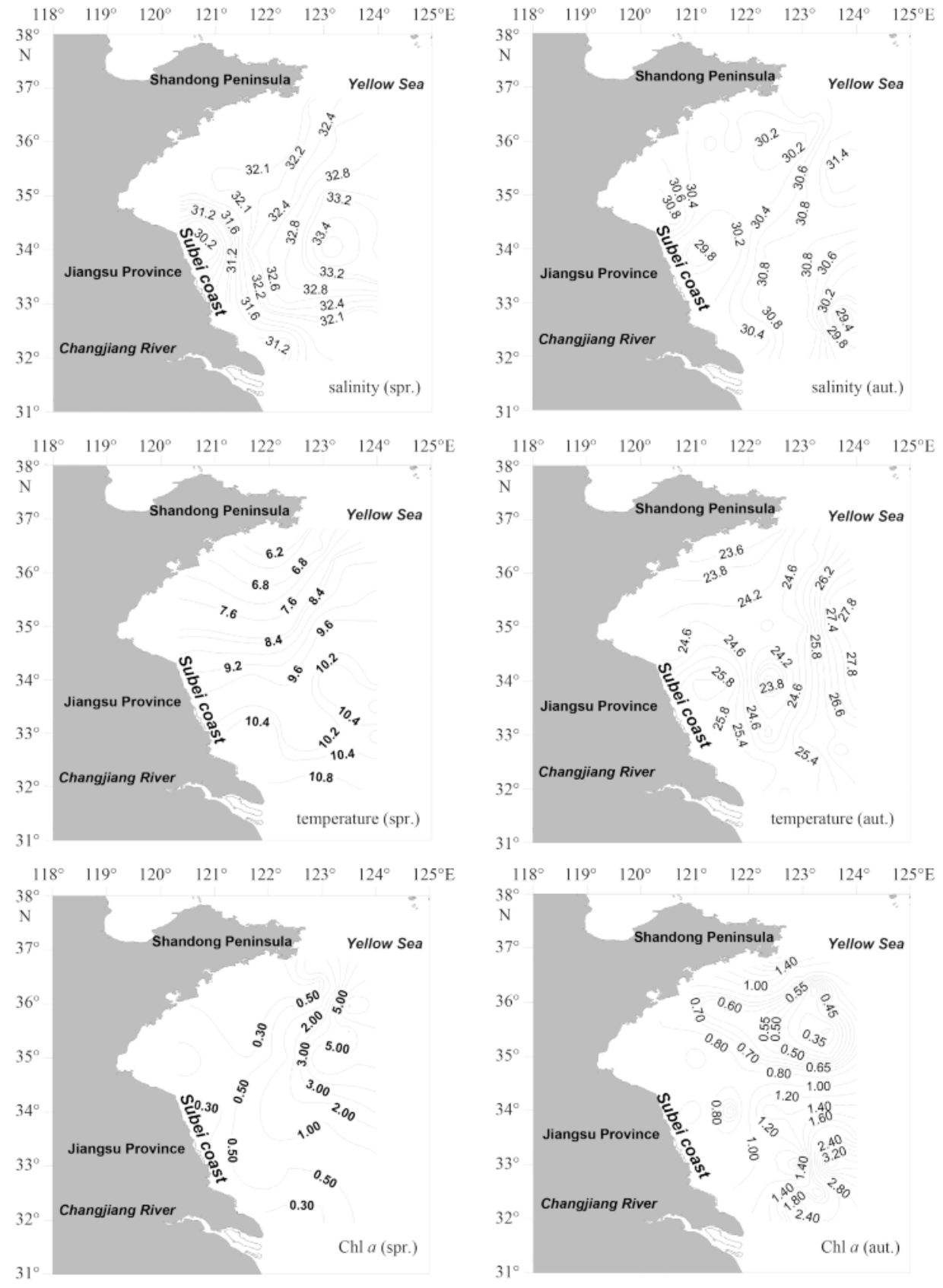

Fig. 2. 

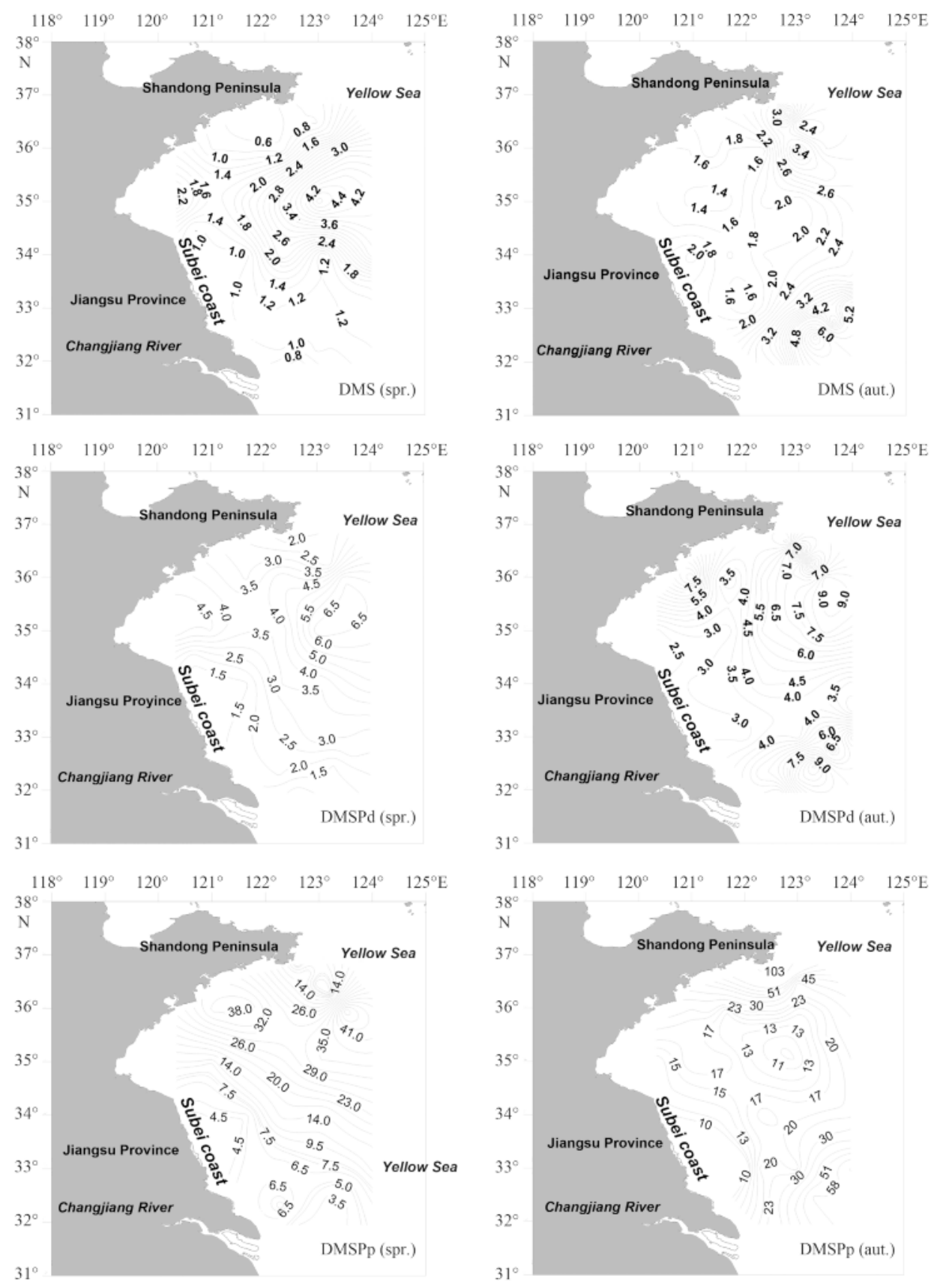

Fig. 2. Horizontal distributions of salinity, temperature $\left({ }^{\circ} \mathrm{C}\right)$, chlorophyll $a$ concentration $(\mu \mathrm{g} / \mathrm{L})$, DMS, DMSPd and DMSPp concentrations (nmol/L) in spring (spr.) and autumn (aut.).

status in various coastal and shelf waters (Lefèvre et al., 2002; Michaud et al., 2007; Shenoy and Patil, 2003). We found that the average temperature in autumn cruise was 2.7 times higher than that in spring, which was close to sea-surface temperature in summer. These result indicated that the growth of phytoplankton was still relatively exuberant during autumn cruise, due to the higher sea-surface temperature. Chlorophyll $a$ concentrations in autumn cruise were generally higher than those in spring cruise except for a few stations (H08, H09 and H11) in spring bloom region. Besides, it is well known that dinoflagellates contain more DMSP than diatoms. Song (2010) found that the contributions of diatoms and dinoflagellates to phytoplankton biomass in the SYS in spring were $92.2 \%$ and $7.19 \%$, respectively, while their contributions were $78.59 \%$ and $17.29 \%$ in autumn. As a consequence, DMS, DMSPd and DMSPp concentrations in autumn were approximately twice as high as those in spring.

In spring, elevated levels of DMS and DMSP concentrations were found in the middle region of the SYS, which were obviously higher than those observed in the coastal areas. Huang et al. (2006) suggested that the spring bloom was initiated due to the interaction of sufficient nutrients accumulated during the winter and the increase in water temperature. Owing to the phytoplankton bloom in the middle region of the SYS, the highest concentration of DMSPp was recorded at Sta. H8 with the highest level of chlorophyll $a$. The maximum values of DMS and DMSPd appeared at Sta. H11 in the center of the SYS. In comparison, the concentrations of these sulfur compounds in autumn generally 
decreased from the coast of the Shandong Peninsula to the central SYS (Fig. 2). The highest value of DMSPp (137.87 nmol/L) appeared at Sta. B04 located at the inshore of the Shandong Peninsula. The low values of DMS and DMSP appeared in the central part of the SYS with the bloom decline and the lowest value of DMS was recorded at Sta. H15 in the central part of SYS. According to the investigation of Shang (2011), the Yellow Sea Cold Water Mass still exists in the bottom waters on the north of $34^{\circ} \mathrm{N}$ in autumn. Owing to the water stratification and the presence of the thermocline (Wang, 2000), nutrients in the upper layer were exhausted by organisms during summer and could not be replenished by the nutrient-rich waters at the bottom, which limited the algal growth and led to low DMS and DMSP values in the central part of the SYS.

In spring, the lower DMS and DMSP levels appeared in the adjacent area of the Changjiang River Estuary, which corresponded well with the lower salinities here (Fig. 2). The lowest values of DMS, DMSPd and DMSPp were respectively recorded at Stas $\mathrm{H} 40, \mathrm{H} 40$ and H42, respectively, which were located near the Changjiang River Estuary. On the contrary, the high concentrations of sulfur compounds in autumn were found in the adjacent area of the Changjiang River estuary and the highest values of DMS and DMSPd concentrations were concurrently found at Sta. H40. The Changjiang River had a momentous influence on the distributions of DMS and DMSP in the south of the study area in April and September. As the material basis of life activities of phytoplankton, nutrients in sea water can affect the algal growth and reproduction, then change the phytoplankton community structure (Fu et al., 2012), and ultimately influence the distributions of DMS and DMSP. The Changjiang River diluted water is hypohaline waters (salinities of 5-31) with rich nutrients, and has an important effect on the Yellow Sea and the East China Sea by forming obvious gradient of salinity and nutrients (Wang et al., 2003). From May to September, under the combined functions of the southwestern monsoon and higher runoff, the direction of the Changjiang River diluted water gradually turns to the north and it enters the southwest area of the SYS (Cui, 1984; Chen, 2007). Compared with the spring, the nutrients in autumn, including DIN and $\mathrm{PO}_{4}-\mathrm{P}$, all exhibited relatively high concentrations in the southwest area of the SYS (Fig. 3), which promoted the phytoplankton growth and thus led to higher concentrations of chlorophyll $a$, DMS and DMSP in this region.

In addition, vertical turbulent dispersion can lead to poor stability of water column and is not favorable to increase the number of phytoplankton and keep its density in the surface layer of the south of $34^{\circ} \mathrm{N}$ (Hu et al., 2004), thereby influencing the concentrations of DMS and DMSP. A similar conclusion was proposed by other authors in different waters. For example, Froneman et al. (2004) pointed out that the higher chlorophyll $a$ biomass and biological production depended on the water column stability. Hashihama et al. (2008) suggested that the weak stratification potentially prevented the optimal growth of large diatoms. On the south of $34^{\circ} \mathrm{N}$, the mixed layer depths in autumn were obviously lower than those in spring (Tables 1 and 2), which resulted in the stronger stability of the water layer and the higher chlorophyll $a$ concentrations in autumn. Hu et al. (2004) reported that the concentrations of chlorophyll $a$ significantly depended on the stability of the water layer and high concentrations of chlorophyll $a$ appeared in the offshore waters on the south of $34^{\circ} \mathrm{N}$ from May to September, due to the weaker vertical turbulent dispersion. Therefore, high concentrations of DMS and DMSP in this area were also attributed to the strong stability of the water layer in autumn.

Finally, the lower concentrations of DMS and DMSP were found in the Subei coastal waters and the adjacent area of the Changjiang River Estuary in spring and autumn. The lower salinities here indicated that coastal area was influenced by the terrestrial runoff and the Changjiang River diluted water. Although high concentrations of nutrients were brought by the terrestrial runoff and the Changjiang River diluted water, lower transparency in coastal region limited the growth of phytoplankton, which resulted in the lower levels of chlorophyll $a$ concentration (Hu et al., 2004) and thus lower concentrations of DMS and DMSP here.

In conclusion, biomass and composition of phytoplankton were the immediate causes which led to the seasonal differences in the DMS and DMSP concentrations distributions between spring and autumn. Besides, the seasonal variations of DMS and DMSP concentrations in the SYS were indirectly controlled by the differences in the temperature, nutrients and the water column stability between the two seasons.

\subsection{Influencing factors of DMS and DMSP concentrations in the SYS}

During the two cruises, the distributions of DMS and DMSP concentrations showed a high degree of spatial heterogeneity and large seasonal fluctuation. These differences were largely due to the seasonal variations in the marine biological and environmental factors.

It is well known that DMSP can serve as the cryoprotectants and osmotic pressure regulator in algae cells (Vairavamurthy et al., 1985; Karsten et al., 1992). Therefore, the salinity and temperature can significantly affect the DMS and DMSP concentrations. However, our results show that no correlations are found between DMS concentration, DMSP concentration and the temperature (Table 3). As shown in Tables 1 and 2, the values of temperature in spring and autumn fluctuated from 5.74 to 11.20 and from 22.64 to $27.99^{\circ} \mathrm{C}$, respectively. The results indicated that the smaller temperature differences have no significant influence on DMS and DMSP concentrations. Therefore, the temperature cannot be a main limiting factor for the DMS and DMSP concentrations. Similar to the temperature, there were no correlations between DMS concentration, DMSP concentration and the salinity in spring and autumn (Table 3). Although DMSP plays a role in osmotic adjustment, the change of its concentration according to osmotic demands is very slow (Kirst, 1996). Thus, there were no obvious correlations between DMS concentration, DMSP concentration and the salinity.

Since DMS and DMSP originate from marine phytoplankton, chlorophyll $a$ is possibly one of the primary controlling factors of DMS and DMSP. Some attempts have been made to find possible relationships between the biogenic sulfur compounds and chlorophyll $a$. To date, some authors have reported the significant correlations between DMS, DMSPp and chlorophyll $a$ (Andreae et al., 1990; Yang et al., 1999, 2011; Zhang et al., 2008, 2009), whereas others have found poor or no correlations (Besiktepe et al., 2004; Holligan et al., 1987; Simó et al., 1997; Turner et al., 1988; Vila-Casta et al., 2008). The difficulties in obtaining a general correlation are usually attributed to the fact that the DMS concentration level in sea water largely depends on the phytoplankton population structure and biomass, and different sea regions have different species composition and abundance.

In spring, the significant correlations appeared between the DMS, DMSPd, DMSPp and chlorophyll $a$ concentrations (Table 3 ), which was consistent with previous study in the Yellow Sea 

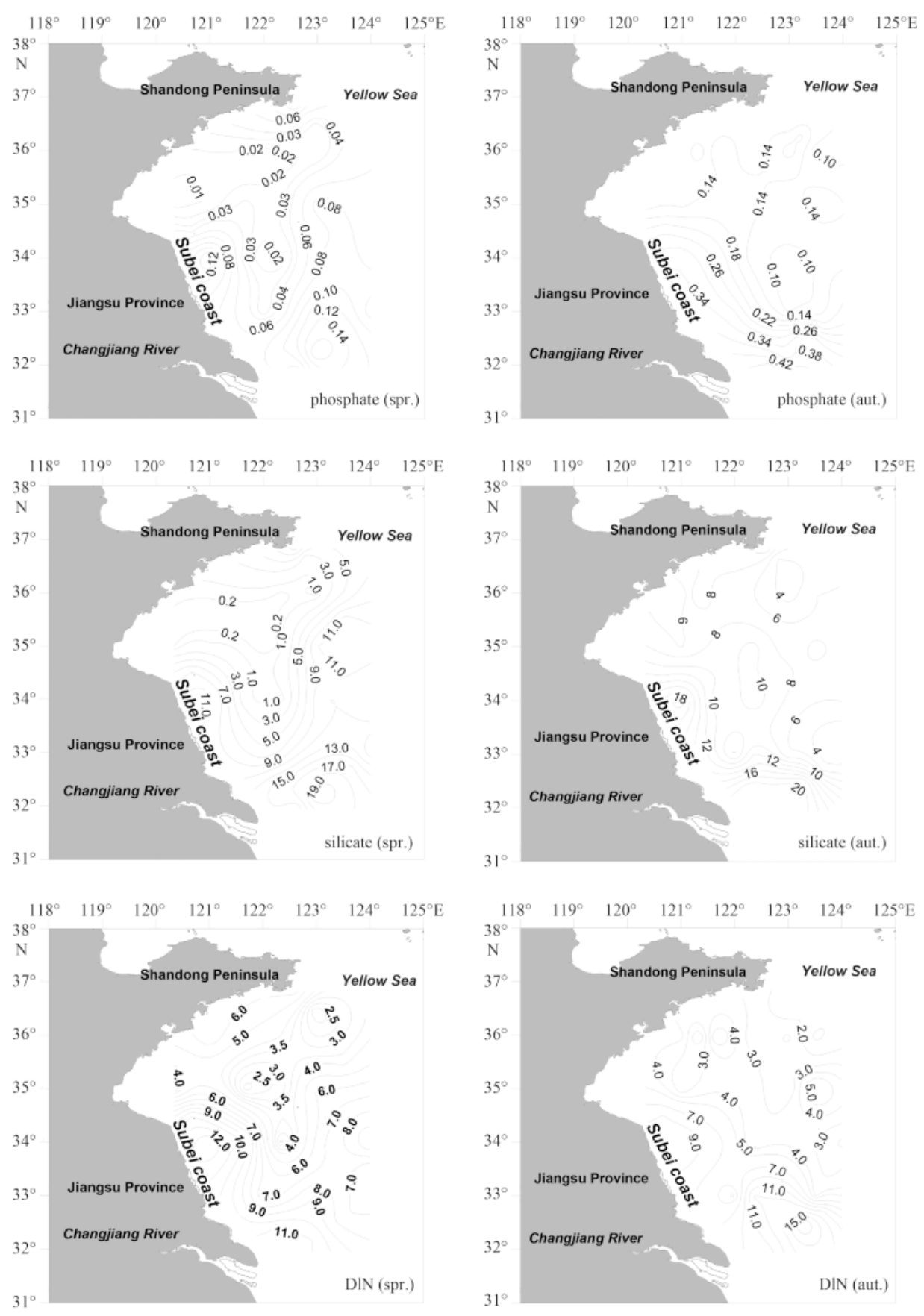

Fig. 3. Horizontal distributions of DIN, phosphate and silicate concentrations ( $\mu \mathrm{mol} / \mathrm{L}$ ) in spring (spr.) and autumn (aut.).

Table 3. Relationships between DMS, DMSP concentrations and the marine biological and environmental factors in the SYS in spring and autumn

\begin{tabular}{|c|c|c|c|c|c|c|}
\hline & \multicolumn{3}{|c|}{ Spring } & \multicolumn{3}{|c|}{ Autumn } \\
\hline & $n$ & $r^{2}$ & $P$ & $n$ & $r^{2}$ & $P$ \\
\hline DMS vs Chl $a$ & 31 & 0.453 & $3.000 \times 10^{-5}$ & 33 & 0.268 & 0.002 \\
\hline DMS vs $T$ & 31 & 0 & 0.991 & 33 & 0.071 & 0.133 \\
\hline DMS vs $S$ & 31 & 0.188 & 0.015 & 33 & 0.002 & 0.808 \\
\hline DMSPd vs Chl $a$ & 31 & 0.458 & $2.920 \times 10^{-5}$ & 33 & 0.018 & 0.456 \\
\hline DMSPd vs $T$ & 31 & 0.021 & 0.013 & 33 & 0.026 & 0.370 \\
\hline DMSPd vs $S$ & 31 & 0.267 & 0.242 & 33 & 0.052 & 0.203 \\
\hline DMSPp vs Chl $a$ & 31 & 0.414 & $9.540 \times 10^{-5}$ & 33 & 0.276 & 0.002 \\
\hline DMSPp vs $T$ & 31 & 0.090 & 0.100 & 33 & 0.012 & 0.546 \\
\hline DMSPp vs $S$ & 31 & 0.097 & 0.088 & 33 & 0.011 & 0.853 \\
\hline
\end{tabular}


(Zhang et al., 2008). This result indicates that the phytoplankton biomass may play an important role in controlling the distributions of DMS and DMSP in the SYS in spring. In contrast, weak correlations were found between DMS or DMSPp and chlorophyll $a$ concentrations in the autumn cruise (Table 3). Previous studies have shown that a good relationship is to be expected only where the phytoplankton assemblage is dominated by certain type of algae (Dacey et al., 1998). Since a phytoplankton bloom took place in spring, the taxonomic composition of phytoplankton in spring might be more unitary in spring than in autumn. Xu (2007) reported that the percentage of diatoms in the total phytoplankton abundance was $99.63 \%$ in the SYS during the spring bloom, while the proportion of dinoflagellates accounted for only $0.37 \%$ in the same period. Wang $(2001,2003)$ pointed that a total of 72 species that belonged to 29 genera were identified in autumn, while a total of 29 species were determined belonging to 14 genera in spring in the Huanghai Sea. In summary, the composition of phytoplankton was more unitary in spring and thus the notable relationship appeared between DMS or DMSPp and chlorophyll $a$ in spring.

\subsection{Seasonal variations of DMS(P)-to-chlorophyll a concentra- tions ratios in SYS}

Since the concentration of chlorophyll $a$ varies with different phytoplankton species and the ability to form DMS and DMSP is controlled by the phytoplankton species, the ratio of DMS to chlorophyll a concentrations can be used for calculating the DMS production ability per unit biomass and the ratio of DMSPp to chlorophyll a concentrations can be utilized as an estimate of the proportion of DMSP producers in the total phytoplankton assemblage (Turner et al., 1995). In the spring cruise, the ratios of DMSPp to chlorophyll a concentrations range from 4.54 to 234.27 $\mathrm{mmol} / \mathrm{g}$, with an average of $27.66 \mathrm{mmol} / \mathrm{g}$ and the ratios of DMS to chlorophyll $a$ concentrations varied from 0.29 to $7.01 \mathrm{mmol} / \mathrm{g}$, with a mean value of $2.31 \mathrm{mmol} / \mathrm{g}$. In the autumn cruise, the ratios of DMS to chlorophyll $a$ concentrations and DMSPp to chlorophyll $a$ concentrations range from 0.86 to $10.92 \mathrm{mmol} / \mathrm{g}$ and from 6.65 to $116.04 \mathrm{mmol} / \mathrm{g}$, respectively, with mean values of 3.31 and $30.62 \mathrm{mmol} / \mathrm{g}$.

In the present study, the seasonal differences in the ratios of DMS to chlorophyll $a$ concentrations and DMSPp to chlorophyll $a$ concentrations are evident between spring and autumn (Fig. 4). In spring, the lower ratio values of DMS to chlorophyll $a$ concentrations and DMSPp to chlorophyll $a$ concentrations appeared in the central part of the SYS with the algal bloom (e.g., Stas H07, H08, H09 and H11). On the contrary, the high ratios of DMS to chlorophyll $a$ concentrations and DMSPp to chlorophyll $a$ concentrations were found in these regions in autumn. On the south of $34^{\circ} \mathrm{N}$, the ratios of DMSPp to chlorophyll $a$ concentrations at most stations in autumn are higher than those in spring. Besides, the average ratio of DMS/chlorophyll $a$ in spring $(2.31 \mathrm{mmol} / \mathrm{g})$ is significantly lower than that in autumn $(3.31 \mathrm{mmol} / \mathrm{g})$ and the mean ratio of DMSPp to chlorophyll $a$ concentrations in spring $(27.66 \mathrm{mmol} / \mathrm{g})$ is also lower than that in autumn $(30.62$ $\mathrm{mmol} / \mathrm{g}$ ). This result indicates that although diatoms are the dominant species in the SYS, the proportion of diatoms in total
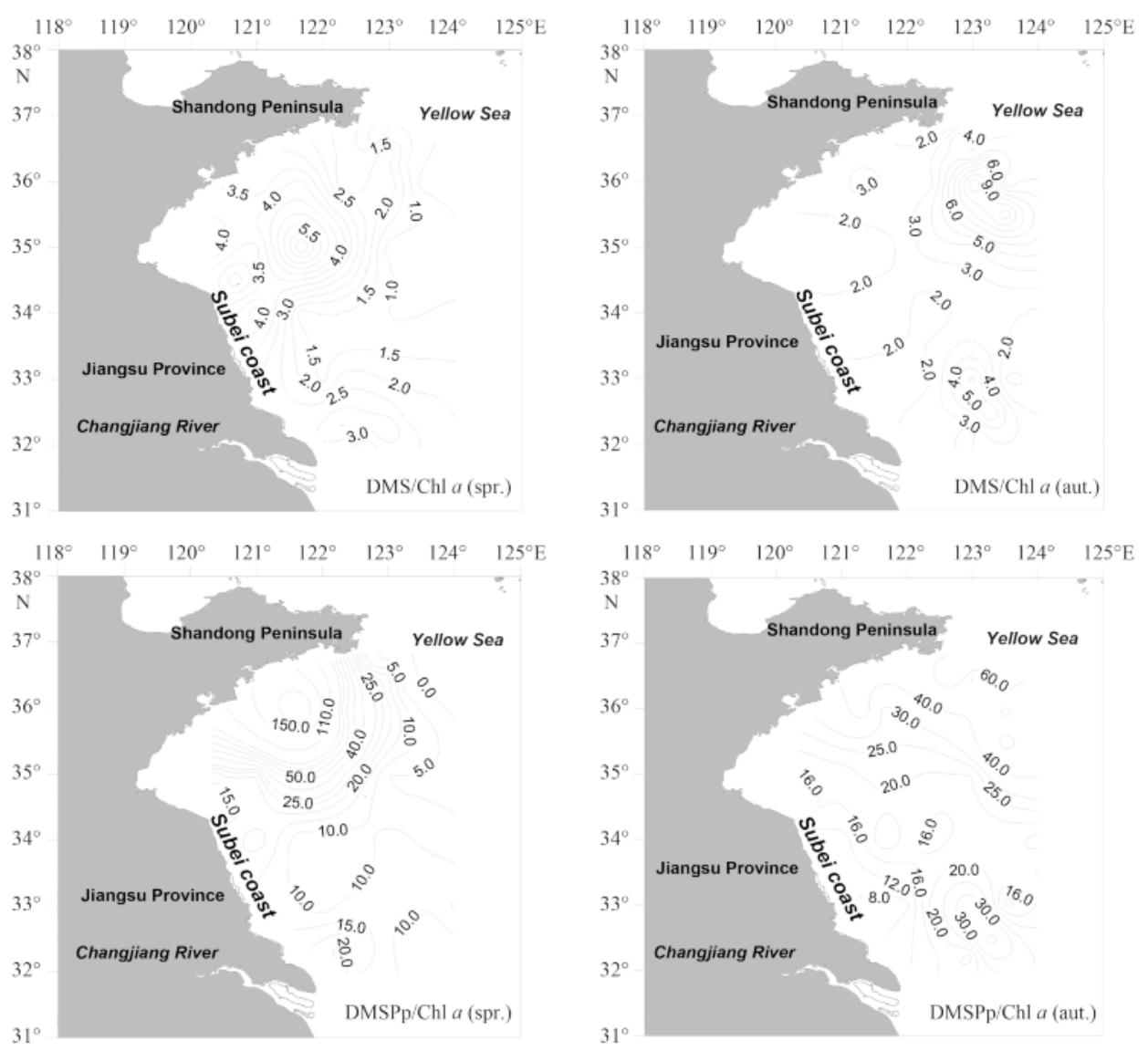

Fig. 4. Horizontal distributions of the ratios of DMS to chlorophyll $a$ concentrations and DMSPp to chlorophyll $a$ concentrations in spring (spr.) and autumn (aut.). 
phytoplankton assemblage changes with seasons and dinoflagellates biomass in the SYS is higher in autumn than in spring.

Some authors have proposed that the phytoplankton community structure is affected by the change in the concentrations and proportions of nutrients (Iverson et al., 1989; Wang, 2003). Previous studies pointed that the uptake rate of phosphate by diatoms was faster than that of DIN, while the nutrient utilizations by dinoflagellates are just the opposite (Dong et al., 2002). Thus, the higher ratios of DIN to $\mathrm{PO}_{4}^{3-}$ concentrations usually appeared in the region dominated by diatoms, while the lower ratios of DIN to $\mathrm{PO}_{4}^{3-}$ concentrations are generally accompanied by the increase of dinoflagellates biomass. In the present study, the ratios of DIN to $\mathrm{PO}_{4}^{3-}$ concentrations in the SYS are obvi- ously higher in spring than in autumn (Fig. 5). This result indicates that although diatoms are the dominant species in the SYS, the proportion of diatoms in total phytoplankton assemblage changes with seasons and dinoflagellates biomass in the SYS is higher in autumn than in spring. Liu (2007) reported that in the SYS, the average cell abundance of dinoflagellates at each station was $2.44 \times 10^{4}$ cells $/ \mathrm{m}^{3}$ in the SYS during autumn, which was obviously higher than that $\left(0.74 \times 10^{4}\right.$ cells $\left./ \mathrm{m}^{3}\right)$ in spring. Since the composition of phytoplankton in the SYS changes with season, with the increased abundance of dinoflagellates and the decreased diatoms proportion in autumn, the ratios of DMS or DMSPp to chlorophyll $a$ are correspondingly increased in the autumn cruise.
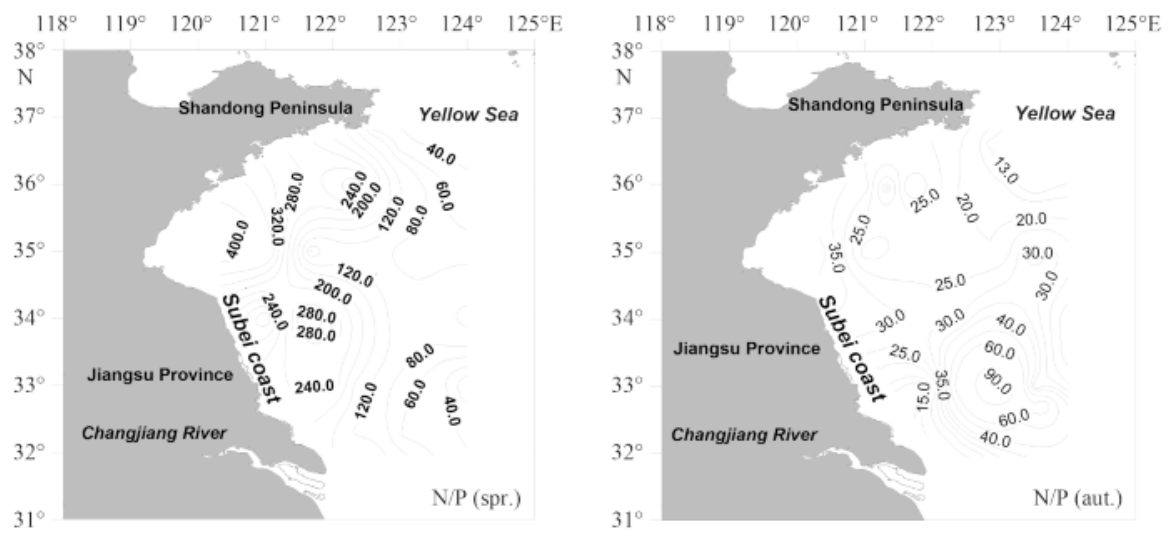

Fig. 5. Horizontal distributions of the ratios of nitrogen to phosphorus concentrations in spring (spr.) and autumn (aut.).

\subsection{Sea-to-air flux of DMS in SYS}

The mean fluxes obtained by the methods of LM86 and W92 are $3.03(0.021-13.79)$ and $6.92(0.054-32.50) \mu \mathrm{mol} /(\mathrm{m} \cdot \mathrm{d})$ in spring and $3.41(0.020-17.86)$ and $7.81(0.015-39.45) \mu \mathrm{mol} /(\mathrm{m} \cdot \mathrm{d})$ in autumn, respectively. In the study area, the range of DMS seato-air fluxes exceeded three to four orders of magnitude, due to the obvious differences of DMS concentrations and the wind speeds among sample stations. In addition, although the mean wind speed in spring $(6.74 \mathrm{~m} / \mathrm{s})$ is higher than that in autumn (5 $\mathrm{m} / \mathrm{s}$ ), the average sea-to-air flux of DMS in spring was lower than that in autumn. This might be attributed to apparently higher
DMS concentrations in autumn than in spring. In order to facilitate the comparison with the previous studies, the DMS flux estimates for the HS in previous studies are summarized in Table 4. Our results in spring and autumn are in good agreement with those previously reported by Yang et al. (2006) and Hu et al. (2003). However, our results in spring are much lower than those previously reported by Zhang et al. (2008). The influence of large DMS concentration (Zhang et al., 2008) resulted in the higher flux to the atmosphere.

Combined with previously published experimental results in summer and winter (Yang et al., 2011), the mean annual fluxes of

Table 4. Summary of sea-to-air fluxes of DMS from the HS in literature

\begin{tabular}{|c|c|c|c|c|c|}
\hline Study area & Time & $\begin{array}{c}\text { DMS concentration/ } \\
\mathrm{nmol} \cdot \mathrm{L}^{-1}\end{array}$ & $\begin{array}{c}\text { Wind speed/ } \\
\mathrm{m} \cdot \mathrm{s}^{-1}\end{array}$ & $\begin{array}{c}\text { DMS fluxes } \\
\mu \mathrm{mol} \cdot \mathrm{m}^{-2} \cdot \mathrm{d}^{-1}\end{array}$ & Reference \\
\hline Yellow Sea & September 1994 & $2.89(0.95-7.48)$ & - & $4.54(0.11-18.88)$ & Hu et al. (2003) \\
\hline Yellow Sea & March 2005 & $2.31(1.20-4.54)$ & $0.3-10.4$ & $3.14(0.01-5.68)$ & Yang et al. (2006) \\
\hline Yellow Sea & April 2006 & $5.42(1.78-12.75)$ & $0.5-10.8$ & $6.41(0.04-20.76)$ & Zhang et al. (2008) \\
\hline Yellow Sea & April 2010 & $1.69(0.48-4.92)$ & $0.9-15.2$ & $3.03(0.021-13.79)$ & this study \\
\hline Yellow Sea & September 2010 & $2.80(1.33-7.95)$ & $1.1-10.6$ & $3.41(0.020-17.86)$ & this study \\
\hline
\end{tabular}

4.02 and $9.07 \mu \mathrm{mol} /\left(\mathrm{m}^{2} \cdot \mathrm{d}\right)$ are calculated, respectively, according to the models of LM86 and W92. The annual DMS emission rates ranged from 0.015 to $0.033 \mathrm{Tg} / \mathrm{a}$ (calculated by S), taking the result by LM86 as a lower limit and the result by W92 as an upper limit. According to preliminary estimate, the annual DMS emission from the SYS accounted for $0.10 \%-0.22 \%$ of total annual emission (15 Tg/a) (Kettle and Andreae, 2000). Since the SYS occupies only a small part $(0.08 \%)$ of the world ocean, our result in- dicates that the net DMS emission from the SYS may represent a non-negligible amount to the local and global oceanic DMS fluxes.

\section{Conclusions}

The temporal distributions of DMS, DMSP and chlorophyll $a$ in the SYS were investigated in the present study. The higher DMS and DMSP concentrations were observed in the central part 
of the SYS in spring. The significant correlations between DMS, DMSPp and chlorophyll $a$ concentrations were found only in spring, due to the phytoplankton bloom. On the south of $34^{\circ} \mathrm{N}$, DMS and DMSP concentrations show the high values in the southwest of the SYS in autumn, which is attributed to the stronger stability of the water body and the input of nutrients in the Changjiang River diluted water. Our data showed that the concentrations and distributions of DMS and DMSP in spring and autumn are directly influenced by the seasonal variations in the phytoplankton composition and abundance. Moreover, different environmental factors (e.g., nutrients, water column stability and the Changjiang River effluent) also exhibited the significant impacts on the distributions of DMS and DMSP. The annual DMS emission rates ranged from 0.015 to $0.033 \mathrm{Tg} / \mathrm{a}$, taking the result by LM86 as a lower limit and the result by W92 as an upper limit, which accounted for $0.10 \%-0.22 \%$ of total annual DMS emission in the world ocean. The SYS occupies only a small part $(0.08 \%)$ of the world ocean, and thus the emission of DMS from the study area has a significant relative contribution to the global oceanic DMS fluxes.

\section{Acknowledgements}

The authors are grateful to the captain and crew of the R/V Dongfanghong No. 2 for help and cooperation during the two cruises. We also wish to thank the colleagues in our laboratory for the assistance in sample collection and pretreatment. Moreover, we thank Li Chengxuan for her help in analyzing DMS sample during two cruises.

\section{References}

Andreae M O. 1990. Ocean-atmosphere interactions in the global biogeochemical sulfur cycle. Marine Chemistry, 30: 1-29

Bates T S, Cline J D, Gammon R H, et al. 1987. Regional and seasonal variations in the flux of oceanic dimethylsulfide to the atmosphere. Journal of Geophysical Research, 92(C3): 2930-2938

Bates T S, Kiene R P, Wolfe G V, et al. 1994. The cycling of sulfur in surface seawater of the Northeast Pacific. Journal of Geophysical Research, 99(C4): 7835-7843

Besiktepe S, Tang K W, Vila M, et al. 2004. Dimethylated sulfur compounds in seawater, seston and mesozooplankton in the seas around Turkey. Deep Sea Research Part I: Oceanographic Research Papers, 51(9): 1179-1197

Charlson R J, Lovelock J E, Andreae M O, et al. 1987. Oceanic phytoplankton, atmospheric sulphur, cloud albedo and climate. Nature, 326(6114): 655-661

Chen Yizhong. 2007. Numerical simulation of seasonal Changes of the circulation and Changjiang diluted water in the Yellow Sea and East China Sea (in Chinese) [dissertation]. Shanghai: East China Normal University

Cui Maochang. 1984. A study on the direction change of the Changjiang river diluted water. Oceanologia et Limnologia Sinica (in Chinese), 15(3): 222-229

Dacey J W H, Blough N V. 1987. Hydroxide decomposition of dimethylsulfoniopropionate to form dimethylsulfide. Geophysical Research Letters, 14(12): 1246-1249

Dacey J W H, Howse F A, Michaels A F, et al. 1998. Temporal variability of dimethylsulfide and dimethylsulfoniopropionate in the Sargasso Sea. Deep Sea Research Part I: Oceanographic Research Papers, 45(12): 2085-2104

Dacey J W H, Wakeham S G. 1986. Oceanic dimethylsulfide: Production during zooplankton grazing on phytoplankton. Science, 233(4770): 1313-1316

Dong Qing, Liu Haiying, Bi Yuanpu, et al, 2002. Ecological study on planktonic dinoflagellates in inshore of Northern Yellow Sea. Marine Fisheries Research (in Chinese), 23(4): 46-50

Froneman P W, Pakhomov E A, Balarin M G. 2004. Size-fractionated phytoplankton biomass, production and biogenic carbon flux in the eastern Atlantic sector of the Southern Ocean in late austral summer 1997-1998. Deep Sea Research Part II: Topical Studies in Oceanography, 51(22-24): 2715-2729

Fu Mingzhu, Wang Zongling, Pu Xinming, et al. 2012. Changes of nutrient concentrations and N: P: Si ratios and their possible impacts on the Huanghai Sea ecosystem. Acta Oceanologica Sinica, 31(4): 101-112

Galí M, Saló V, Almeda R, et al. 2011. Stimulation of gross dimethylsulfide (DMS) production by solar radiation. Geophysical Research Letters, 38(15): L15613

Hashihama F, Hirawake T, Kudoh S, et al. 2008. Size fraction and class composition of phytoplankton in the Antarctic marginal ice zone along the $140^{\circ} \mathrm{E}$ meridian during February-March 2003. Polar Science, 2(2): 109-120

Holligan P M, Turner S M, Liss P S. 1987. Measurements of dimethyl sulphide in frontal regions. Continental Shelf Research, 7(2): 213-224

Hu Min, Tang Xiaoyan, Li Jinlong, et al. 2003. Distributions of dimethylsulfide in the Bohai Sea and Yellow Sea of China. Journal of Environmental Sciences, 15(6): 762-767

Hu Haoguo, Wan Zhenwen, Yuan Yeli. 2004. Simulation of seasonal variation of phytoplankton in the southern Huanghai (Yellow) Sea and analysis on its influential factors. Haiyang Xuebao (in Chinese), 26(6): 74-88

Huang Bangqin, Liu Yuan, Chen Jixin, et al. 2006. Temporal and spatial distribution of size-fractionized phytoplankton biomass in East China Sea and Huanghai Sea. Haiyang Xuebao (in Chinese), 28(2): 156-164

Iverson R L, Nearhoof F L, Andreae M O. 1989. Production of dimethylsulfonium propionate and dimethylsulfide by phytoplankton in estuarine and coastal waters. Limnology and Oceanography, 34(1): 53-67

Karsten U, Wiencke C, Kirst G O. 1992. Dimethylsulphoniopropionate (DMSP) accumulation in green macioalgae from polar to temperate regions: interactive effects of light versus salinity and light versus temperature. Polar Biology, 12(6): 603-607

Keller M D, Bellows W K, Guillard R R L. 1989. Dimethyl sulfide production in marine phytoplankton. In: Saltzman E S, Cooper W J, eds. Biogenic Sulfur in the Environment. Washington, DC, USA: American Chemical Society, 167-182

Kettle A J, Andreae M O. 2000. Flux of dimethylsulfide from the oceans: A comparison of updated data sets and flux models. Journal of Geophysical Research, 105(D22): 26793-26808

Kirst G O. 1996. Osmotic adjustment in phytoplankton and macroalgae: The use of dimethylsulfoniopropionate (DMSP). In: Kiene R P, Visscher P T, Keller M D, et al., eds. Biological and Environmental Chemistry of DMSP and Related Sulfonium Compounds. US: Springer, 121-130

Lee G, Park J, Jang Y, et al. 2010. Vertical variability of seawater DMS in the South Pacific Ocean and its implication for atmospheric and surface seawater DMS. Chemosphere, 78(8): 1063-1070

Lefèvre M, Vézina A, Levasseur M, et al. 2002. A model of dimethylsulfide dynamics for the subtropical North Atlantic. Deep Sea Research Part I: Oceanographic Research Papers, 49(12): 2221-2239

Levasseur M, Michaud S, Egge J, et al. 1996. Production of DMS and DMSP during a mesocosm study of an Emiliania huxleyi bloom: influence of bacteria and Calanus finmarchicus grazing. Marine Biology, 126(4): 609-618

Li Chengxuan, Yang Guipeng, Pan Jinfen, et al. 2010. Experimental studies on dimethylsulfide (DMS) and dimethylsulfoniopropionate (DMSP) production by four marine microalgae. Acta Oceanologica Sinica, 29(4): 78-87

Liss P S, Merlivat L. 1986. Air-sea gas exchange rates: introduction and synthesis. In: Buat-Menard P, ed. The Role of Air-Sea Exchange in Geochemical Cycling. Netherlands: Springer, 113-127

Liu Lihua. 2007. The community structure and diversity analysis of phytoplankton in the Yellow Sea and the Chang Jiang Estuary Water (in Chinese) [dissertation]. Qingdao: Ocean University of China 
Liu Zhiyu, Wei Hao, Lozovatsky I D, et al. 2008. Late summer stratification, internal waves, and turbulence in the Yellow Sea. Journal of Marine Systems, 77(4): 459-472

Lovelock J E, Maggs R J, Rasmussen R A. 1972. Atmospheric dimethyl sulphide and the natural sulphur cycle. Nature, 237(5356): 452-453

Mask A C, O'Brien J J, Preller R. 1998. Wind-driven effects on the Yellow Sea Warm Current. Journal of Geophysical Research, 103(C13): 30713-30729

Michaud S, Levasseur M, Cantin G. 2007. Seasonal variations in dimethylsulfoniopropionate and dimethylsulfide concentrations in relation to the plankton community in the St. Lawrence Estuary. Estuarine, Coastal and Shelf Science, 71(3-4): 741-750

Nguyen B C, Mihalopoulos N, Putaud J P, et al. 1992. Covariations in oceanic dimethyl sulfide, its oxidation products and rain acidity at Amsterdam Island in the southern Indian Ocean. Journal of Atmospheric Chemistry, 15(1): 39-53

Parsons T R, Maita Y, Lalli C M. 1984. A Manual of Chemical and Biological Methods for Seawater Analysis. New York: Pergamon Press, 99-112

Saltzman E S, King D B, Holmen K, et al. 1993. Experimental determination of the diffusion coefficient of dimethylsulfide in water. Journal of Geophysical Research, 98(C9): 16481-16486

Shang Rongning. 2011. The distribution and influence factors of Organic Carbon in the Bohai Sea and Yellow Sea of 2010 (in Chinese) [dissertation]. Qingdao: Ocean University of China

Shenoy D M, Patil J S. 2003. Temporal variations in dimethylsulphoniopropionate and dimethyl sulphide in the Zuari estuary, Goa (India). Marine Environmental Research, 56(3): 387-402

Shenoy D M, Paul J T, Gauns M, et al. 2006. Spatial variations of DMS, DMSP and phytoplankton in the Bay of Bengal during the summer monsoon 2001. Marine Environmental Research, 62(2): 83-97

Shenoy D M, Dileep Kumar M, 2007. Variability in abundance and fluxes of dimethyl sulphide in the Indian Ocean. Biogeochemistry, 83(1-3): 277-292

Simó R, Grimalt J O, Albaiglés J. 1997. Dissolved dimethylsulphide, dimethylsulphoniopropionate and dimethylsulphoxide in western Mediterranean waters. Deep Sea Research Part II: Topical Studies in Oceanography, 44(3-4): 929-950

Song Shuqun. 2010. Phytoplankton functional groups in the Yellow Sea and the East China Sea (in Chinese) [dissertation]. Qingdao: Chinese Academy of Sciences

Su Jilan. 1998. Circulation dynamics of the China seas: north of $18^{\circ} \mathrm{N}$ In: Robinson A R, Brink K, eds. The Sea, Vol. 11. The Global Coastal Ocean: Regional Studies and Syntheses. New York: John Wiley, 483-506

Sunda W, Kieber D J, Kiene R P, et al. 2002. An antioxidant function for DMSP and DMS in marine algae. Nature, 418(6895): $317-320$

Turner S M, Malin G, Liss P S, et al. 1988. The seasonal variation of dimethyl sulfide and dimethylsulfoniopropionate concentrations in nearshore waters. Limnology and Oceanography, 33(3): 364-375

Turner S M, Nightingale P D, Broadgate W, et al. 1995. The distribution of dimethyl sulphide and dimethylsulphoniopropionate in Antarctic waters and sea ice. Deep Sea Research Part II: Topical Studies in Oceanography, 42(4-5): 1059-1080

Uher G, Schebeske G, Barlow R G, et al. 2000. Distribution and air-sea gas exchange of dimethyl sulphide at the European western continental margin. Marine Chemistry, 69(3-4): 277-300

Vairavamurthy A, Andreae M O, Iverson R L. 1985. Biosynthesis of dimethylsulfide and dimethylpropiothetin by Hymenomonas carterae in relation to sulfur source and salinity variations. Limnology and Oceanography, 30(1): 59-70

Vila-Costa M, Kiene R P, Simí R. 2008. Seasonal variability of the dy- namics of dimethylated sulfur compounds in a coastal northwest Mediterranean site. Limnology and Oceanography, 53(1): $198-211$

Wang Baodong. 2000. Characteristics of variations and interrelations of biogenic elements in the Huanghai Sea Cold Water Mass. Haiyang Xuebao (in Chinese), 22(6): 47-54

Wang Baodong. 2003. Nutrient distributions and their limitation on phytoplankton in the Yellow Sea and the East China Sea. Chinese Journal of Applied Ecology (in Chinese), 14(7): $1122-1126$

Wang Baodong, Wang Xiulin, Zhan Run. 2003. Nutrient conditions in the Yellow Sea and the East China Sea. Estuarine, Coastal and Shelf Science, 58(1): 127-136

Wang Jun. 2001. Study on phytoplankton in the Yellow Sea in spring. Marine Fisheries Research (in Chinese), 22(1): 56-60

Wang Jun. 2003. Study on phytoplankton in the Yellow Sea in Autumn and winter. Marine Fisheries Research (in Chinese), 24(1): $15-23$

Wanninkhof R. 1992. Relationship between wind speed and gas exchange over the ocean. Journal of Geophysical Research, 97(C5): 7373-7382

Xu Zongjun. 2007. The effect of atmosphere nitrogen deposition on phytoplankton community and marine primary productivity in Yellow Sea and South China Sea in spring (in Chinese) [dissertation]. Qingdao: Ocean University of China

Yang Guipeng, Jing Weiwen, Kang Zhiqiang, et al. 2008. Spatial variations of dimethylsulfide and dimethylsulfoniopropionate in the surface microlayer and in the subsurface waters of the South China Sea during springtime. Marine Environmental Research, 65(1): 85-97

Yang Guipeng, Jing Weiwen, Li Li, et al. 2006. Distribution of dimethylsulfide and dimethylsulfoniopropionate in the surface microlayer and subsurface water of the Yellow Sea, China during spring. Journal of Marine Systems, 62(1-2): 22-34

Yang Guipeng, Levasseur M, Michaud S, et al. 2005. Biogeochemistry of dimethylsulfide (DMS) and dimethylsulfoniopropionate (DMSP) in the surface microlayer and subsurface water of the western North Atlantic during spring. Marine Chemistry, 96(3-4):315-329

Yang Guipeng, Liu Xintong, Li Li, et al. 1999. Biogeochemistry of dimethylsulfide in the South China Sea. Journal of Marine Research, 57(1): 189-211

Yang Guipeng, Zhuang Guangchao, Zhang Honghai, et al. 2012. Distribution of dimethylsulfide and dimethylsulfoniopropionate in the Yellow Sea and the East China Sea during spring: Spatiotemporal variability and controlling factors. Marine Chemistry, 138-139: 21-31

Yang Guipeng, Zhang Honghai, Zhou Limin, et al. 2011. Temporal and spatial variations of dimethylsulfide (DMS) and dimethylsulfoniopropionate (DMSP) in the East China Sea and the Yellow Sea. Continental Shelf Research, 31(13): 1325-1335

Yang Guipeng, Zhang Jianwu, Li Li, et al. 2000. Dimethylsulfide in the surface water of the East China Sea. Continental Shelf Research, 20(1): 69-82

Zhang Honghai, Yang Guipeng, Zhu Tong. 2008a. Distribution and cycling of dimethylsulfide (DMS) and dimethylsulfoniopropionate (DMSP) in the sea-surface microlayer of the Yellow Sea, China, in spring. Continental Shelf Research, 28(17): 2417-2427

Zhang Honghai, Yang Guipeng, Liu Chunying, et al. 2009. Seasonal variations of dimethylsulfide (DMS) and dimethylsulfoniopropionate (DMSP) in the sea-surface microlayer and subsurface water of Jiaozhou Bay and its adjacent area. Acta Oceanologica Sinica, 28(2): 73-86

Zhang S W, Wang Q Y, Lü Y. 2008b. Observation of the seasonal evolution of the Yellow Sea Cold Water Mass in 1996-1998. Continental Shelf Research, 28(3): 442-457 